\title{
Effectiveness of Extension Strategies on Information Dissemination on Mushroom Production
}

\author{
Norhanie Derogongan Hadji Jamel \\ Mindanao State University, Marawi City \\ Lanao del Sur, Philippines
}

\begin{abstract}
The dissemination of information is necessary in every project to make the prospect clientele aware of the goal and significance of the project. This study determines effective strategies on informing the community about the mushroom production carried by the College of Agriculture in Mindanao State University Marawi Campus. A descriptive correlational study was used with the use of survey questionnaire. Respondents of the study were the participants of the trainings and seminars conducted by the College of Agriculture in the university. Findings revealed that location, religion, and occupation are correlated with the lack of materials. Age, civil status, and family income are also correlated with the lack of the extension agent in helping to transfer learning experiences from training to the job situation. The respondents agreed that educational training, information drive and development program help educate the community.
\end{abstract}

Keywords: extension strategies, information dissemination, mushroom production

\section{Introduction}

Now-a-days, information drive is easy due to the emergence and rapid development of information technology. Globalization and global competition is the major concerns among educators particularly in product development in agriculture. According to Yongling (2004) information technology is the major tool in promoting products, information dissemination and marketing all over the world. Commercialization of products is easy and fast through information technology and networking.

Survey and assessments of the quality of products produce in any product developers can be also enhance by using technologies. Gathering of feedbacks from the product is very important in improving the quality of products being produced. Whitaker, et.al, (1994) said that in product development, it is very important to gather information from the consumers particularly in determining their willingness to accept, identification of the target audience, consumers or buyers.

Communication techniques are also important in the dissemination of information. Using various techniques to target audiences or clientele will translate clear ideas and avoid misconceptions. According to the idea of Center for Clinical Decisions and Communications (Eisenberg, nd) effective communication includes tailoring the message, targeting the message to audience, use of narratives, and framing messages. Since mushroom production in the Meranaw community specifically in Marawi City and Lanaodel Sur province is not common thus, information drive about the concept of mushroom production is necessary. Study conducted by Yadav (2008) about technological gap on mushroom production technology among farmers revealed that technological gap has significant relationship on the production aspect of mushrooms. Profile of the farmers such as age, education, caste, social participation, annual income and contact or linkages to extension service providers has contribution to technological gap. Moreover, farmers' knowledge and adoption on mushroom production also showed significant contribution towards technological gap and mushroom production.

Study of Shahi, Kumar, Singh and Kumari (2018) pointed out that vocational training on mushroom production greatly influence mushroom entrepreneur development. They further said that exposure to training increased the farmers knowledge particularly on the different techniques in mushroom productions. As results, farmers tend to cultivate mushroom as their source of livelihood after the training. Today, many countries practice mushroom production. In the Philippines, mushroom farming is not so highly technological as compared to more advance countries in the world despite that mushroom contains high nutritional value. Obaa and Nshemereirwe 
(2004)concluded in their study that mushroom growing is a potential source of livelihood particularly it is easy to market with minimal labor requirements.

Other factors to consider on the extension programs like mushroom production are the socio-cultural upbringing of the community, language barrier and educational attainment. Yadav (2008) mentioned that technological gap and information are hindered by various factors. Some factors include technical know-how, facilities, training exposures, misconceptions about mushrooms and the availability of its market. He said that one way of overcoming the factors are information drive, extension services and farmers' trainings and exposure to the actual mushroom production laboratory. Yadav (2008) concluded that extension service providers should exert extensive efforts to educate the farmers and minimize the technological gap.

Mabuza, Ortmann and Wale (2012) conducted a study on commercial mushroom production by evaluating the role of social capital in the management of farmers groups. Their findings revealed that communication, trust, and teamwork essentials among farmers group engaging mushroom production. Findings of the study conducted by Tanni, Hasan, Hoque, Shamsuzzamanand Moonmoon (2012) showed that mushroom farming experience and product advertisement like media exposure is very important in mushroom cultivation. Furthermore, standard of living and income of mushroom growers significantly improve every year.

Despite of the positive contribution of mushroom cultivation to the livelihood of the cultivators, only few in the Philippines engage mushroom cultivation. According to the study of Kimole (2012), knowledge gap hindered the farmers to grow mushrooms specially the technical skills in handling mushroom cultivation. He also added that group dynamics was not properly addressed particularly between and among stakeholders (e.g. farmers, input suppliers, financial institutions and market outlets) during planning and project implementation.

As such, this study explored effectiveness of extension strategies on information dissemination on mushroom production in the College of Agriculture in Mindanao State University, Marawi Campus, Philippines by having survey among the participants of the different trainings conducted by the college.

\section{Method}

\section{Research Design}

The variable of interest in this study was evaluate the effectiveness of information dissemination on mushroom production carried out by the College of Agriculture, and the stratification factor as by the respondents. Descriptive survey and correlational design was used in determining the relationships of variables investigated.

\section{Respondents}

The respondents of this study were the participants of the trainings and seminars conducted at the College of Agriculture, Mindanao State University, Marawi City. One of the functions of a university is extension services, other than instruction and research. The College of Agriculture has been performing the said function through information dissemination of the new technologies obtained from the results of different researches and studies. It has conducted trainings and seminars including on mushroom production.

Participants were determined through the lists that were obtained from the previous seminars and trainings that have conducted by the College of Agriculture, Mindanao State University, Marawi City on Mushroom Production. Thus, twenty five of the respondents were randomly selected from the participant who came from the province of Lanao del Sur and the other twenty five respondents were participants coming from the province of Lanao del Norte.

\section{Research Instruments and Data Gathering}

This study employed a close-ended questionnaire, for it offers easy comparability of responses. Respondents were allowed to give answers from multiple choices of answers or they will be given answers from which to choose. The questionnaire was composed of four (4) parts. The first part of the questionnaire determined the respondent's personal profile. The second part is on the socio-economic profile of the respondents specifically on the problems that may have been encountered why there is a lack of effectiveness on information dissemination on mushroom production. The third part is on the agricultural extension methods that can be used 
in disseminating information. The respondents indicated: its application on the learning exposure that they have attended and their agreement on its application considering the factor such as time and cost. The fourth and final part is the survey of their professional skills and tasks as extension personnel in conducting trainings or seminar workshops.

Questionnaires were prepared to bring forth information required from the respondents involved in this study. Before the distributions of the questionnaires to the respondents, letter requesting for consent to conduct the research were sent to the authorities concerned. After the approval of the request, the questionnaires were distributed to the respondents with the cover letter, seeking their cooperation and ingenuous answers. The questionnaires were immediately collected after being accomplished. Data were appropriately categorized, tabulated, interpreted, and analyzed using appropriate statistical tools.

\section{Statistical Tools}

The data that gathered were statistically analyzed and interpreted. Statistical computation was done through the use of Statistical Package for Social Sciences (SPSS).

\section{Statistical Results}

\section{Results and Discussions}

Table 1.Respondents' Profile

\begin{tabular}{|c|c|c|c|}
\hline \multirow[t]{2}{*}{ Indicator } & & Frequency $(f)$ & Percentage $(\%)$ \\
\hline & & \multicolumn{2}{|l|}{$\mathrm{N}=50$} \\
\hline \multirow[t]{2}{*}{ Location } & Lanao del Sur & 25 & 50 \\
\hline & Lanao del Norte & 25 & 50 \\
\hline \multirow[t]{4}{*}{ Age (in years) } & Below 30 & 22 & 44 \\
\hline & 30 to 45 & 12 & 24 \\
\hline & 45 to 60 & 13 & 26 \\
\hline & 60 and Above & 3 & 6 \\
\hline \multirow[t]{2}{*}{ Sex } & Male & 21 & 42 \\
\hline & Female & 29 & 58 \\
\hline \multirow[t]{4}{*}{ Civil Status } & Single & 18 & 36 \\
\hline & Married & 27 & 54 \\
\hline & Separated & 1 & 2 \\
\hline & Widowed & 4 & 8 \\
\hline \multirow[t]{3}{*}{ Religion } & Roman Catholic & 31 & 62 \\
\hline & Islam & 18 & 36 \\
\hline & None & 1 & 2 \\
\hline \multirow[t]{5}{*}{ Educational Attainment } & Non formal education & 1 & 2 \\
\hline & Elementary & 1 & 2 \\
\hline & Secondary & 13 & 26 \\
\hline & Tertiary & 28 & 56 \\
\hline & Arabic Education & 7 & 14 \\
\hline \multirow[t]{4}{*}{ Occupation } & Student & 14 & 28 \\
\hline & Government employee & 9 & 18 \\
\hline & Non-government employee & 9 & 18 \\
\hline & Business & 18 & 36 \\
\hline \multirow[t]{3}{*}{ Family Monthly Income } & Below $\square 5,000.00$ & 25 & 50 \\
\hline & $\square 5,000.00$ to $\square 10,000.00$ & 14 & 28 \\
\hline & $\square 10,000.00$ to $\square 20,000.00$ & 6 & 12 \\
\hline
\end{tabular}




\begin{tabular}{llll} 
& $\square 20,000.00$ and Above & 5 & 10 \\
\hline Family Size & Small (1 to 3 members) & 19 & 38 \\
& Average (4 to 6 members) & 18 & 36 \\
Large (more than 6 members) & 13 & 26 \\
\hline
\end{tabular}

Table 2. Effectiveness of Extension Teaching Methods as Perceived by the Respondents

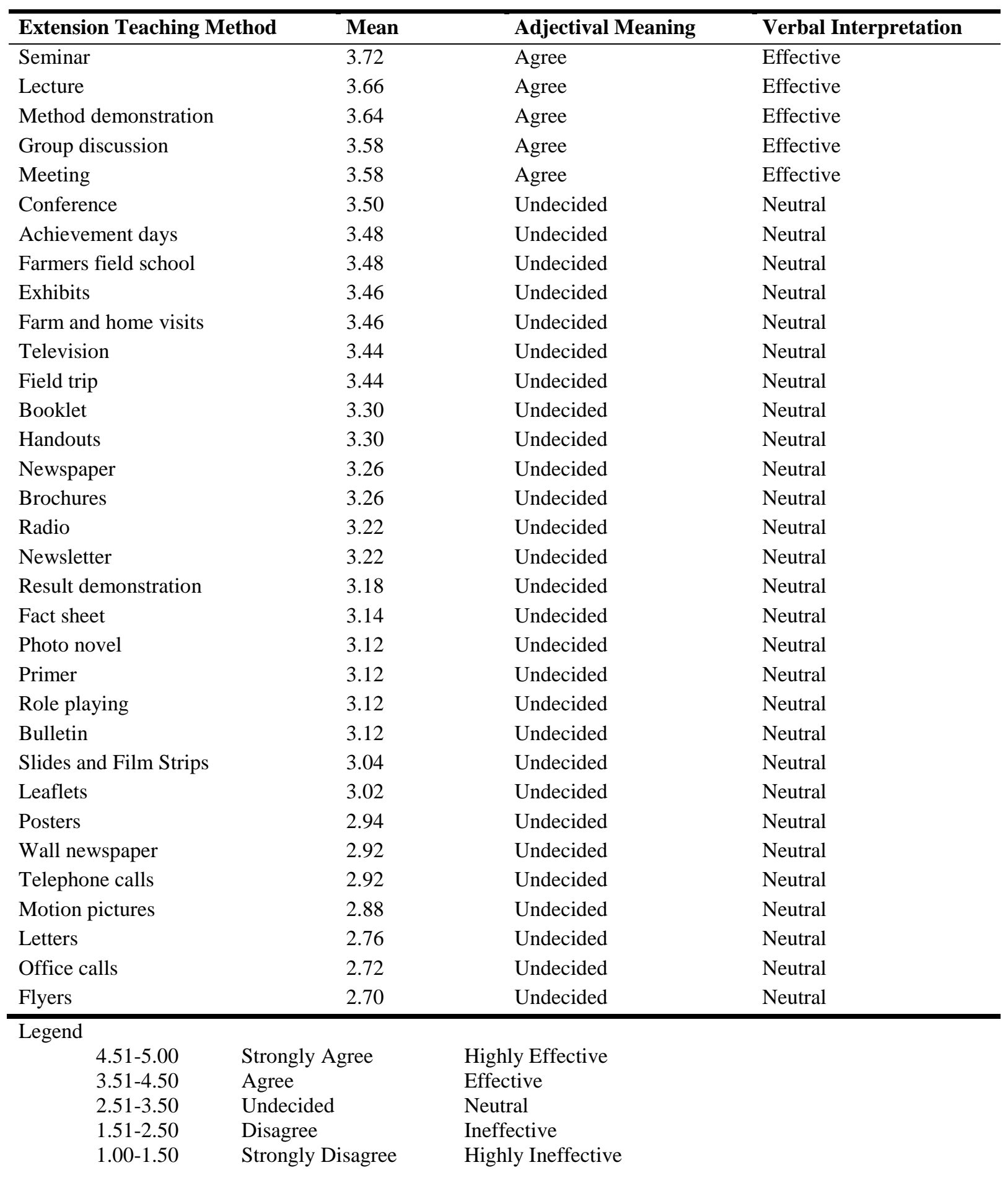


Table 3. Relationship between the Respondents' Profile and the Effectiveness of Technology Transfer

\begin{tabular}{|c|c|c|c|c|}
\hline & & \multirow{2}{*}{$\begin{array}{l}\text { Pearson Chi- } \\
\text { Square Test }\end{array}$} & \multicolumn{2}{|c|}{ Correlation } \\
\hline & & & at 0.05 & at 0.01 \\
\hline \multirow[t]{9}{*}{ Lack of interest } & Location & 0.619 & ns & ns \\
\hline & Age & 8.762 & ns & ns \\
\hline & Sex & 4.013 & ns & ns \\
\hline & Civil Status & 6.649 & ns & ns \\
\hline & Religion & 10.077 & ns & ns \\
\hline & Education & 12.127 & ns & ns \\
\hline & Occupation & 11.605 & ns & ns \\
\hline & Family Monthly Income & 17.210 & ns & ns \\
\hline & Family Size & 14.476 & ns & ns \\
\hline \multirow{9}{*}{$\begin{array}{l}\text { Lack of understanding of the } \\
\text { problems and needs }\end{array}$} & Location & 10.448 & $\mathrm{~s}$ & $\mathrm{~s}$ \\
\hline & Age & 25.938 & $\mathrm{~s}$ & $\mathrm{~s}$ \\
\hline & Sex & 5.043 & ns & ns \\
\hline & Civil Status & 11.282 & ns & ns \\
\hline & Religion & 18.937 & $\mathrm{~s}$ & ns \\
\hline & Education & 7.331 & ns & ns \\
\hline & Occupation & 16.066 & ns & ns \\
\hline & Family Monthly Income & 12.779 & ns & ns \\
\hline & Family Size & 11.511 & ns & ns \\
\hline \multirow{9}{*}{ Lack of information } & Location & 14.160 & $\mathrm{~s}$ & ns \\
\hline & Age & 24.832 & $\mathrm{~s}$ & ns \\
\hline & Sex & 2.135 & ns & ns \\
\hline & Civil Status & 7.858 & ns & ns \\
\hline & Religion & 11.939 & ns & ns \\
\hline & Education & 11.971 & ns & ns \\
\hline & Occupation & 13.312 & ns & ns \\
\hline & Family Monthly Income & 19.520 & ns & ns \\
\hline & Family Size & 13.159 & ns & ns \\
\hline \multirow[t]{9}{*}{ Lack of training } & Location & 12.051 & $\mathrm{~s}$ & ns \\
\hline & Age & 22.470 & $\mathrm{~s}$ & ns \\
\hline & Sex & 2.787 & ns & ns \\
\hline & Civil Status & 9.826 & ns & ns \\
\hline & Religion & 12.460 & ns & ns \\
\hline & Education & 22.259 & ns & ns \\
\hline & Occupation & 25.828 & ns & ns \\
\hline & Family Monthly Income & 17.506 & ns & ns \\
\hline & Family Size & 13.575 & ns & ns \\
\hline \multirow{9}{*}{$\begin{array}{l}\text { Lack of practical training on improved } \\
\text { technology }\end{array}$} & Location & 12.852 & $\mathrm{~s}$ & ns \\
\hline & Age & 27.138 & ns & ns \\
\hline & Sex & 2.284 & ns & ns \\
\hline & Civil Status & 9.784 & ns & ns \\
\hline & Religion & 12.040 & ns & ns \\
\hline & Education & 8.999 & ns & ns \\
\hline & Occupation & 17.252 & ns & ns \\
\hline & Family Monthly Income & 16.195 & ns & ns \\
\hline & Family Size & 8.066 & ns & ns \\
\hline \multirow{7}{*}{$\begin{array}{l}\text { Lack of adequate transportation to } \\
\text { reach other informative events }\end{array}$} & Location & 11.000 & $\mathrm{~s}$ & ns \\
\hline & Age & 25.539 & $\mathrm{~s}$ & ns \\
\hline & Sex & 3.720 & ns & ns \\
\hline & Civil Status & 9.457 & ns & ns \\
\hline & Religion & 24.276 & $\mathrm{~s}$ & $\mathrm{~s}$ \\
\hline & Education & 19.801 & ns & ns \\
\hline & Occupation & 38.314 & $\mathrm{~s}$ & $\mathrm{~s}$ \\
\hline
\end{tabular}




\begin{tabular}{|c|c|c|c|c|}
\hline & Family Monthly Income & 29.037 & $\mathrm{~s}$ & $\mathrm{~s}$ \\
\hline & Family Size & 14.962 & ns & ns \\
\hline \multirow{9}{*}{$\begin{array}{l}\text { Lack of essential teaching and } \\
\text { communication }\end{array}$} & Location & 9.129 & ns & $\mathrm{ns}$ \\
\hline & Age & 18.178 & ns & $\mathrm{ns}$ \\
\hline & Sex & 2.582 & ns & ns \\
\hline & Civil Status & 9.149 & ns & ns \\
\hline & Religion & 11.682 & ns & ns \\
\hline & Education & 26.094 & ns & ns \\
\hline & Occupation & 16.169 & ns & ns \\
\hline & Family Monthly Income & 14.130 & ns & ns \\
\hline & Family Size & 10.826 & ns & ns \\
\hline \multirow[t]{9}{*}{ Lack of access to resources } & Location & 11.110 & $\mathrm{~s}$ & ns \\
\hline & Age & 22.815 & $\mathrm{~s}$ & ns \\
\hline & Sex & 2.112 & ns & ns \\
\hline & Civil Status & 11.045 & ns & ns \\
\hline & Religion & 15.872 & $\mathrm{~s}$ & ns \\
\hline & Education & 19.070 & ns & ns \\
\hline & Occupation & 30.480 & $\mathrm{~s}$ & $\mathrm{~s}$ \\
\hline & Family Monthly Income & 19.118 & ns & ns \\
\hline & Family Size & 21.823 & $\mathrm{~s}$ & $\mathrm{~s}$ \\
\hline \multirow[t]{9}{*}{ Materials are misappropriated } & Location & 5.309 & ns & ns \\
\hline & Age & 32.508 & $\mathrm{~s}$ & $\mathrm{~s}$ \\
\hline & Sex & 5.729 & ns & ns \\
\hline & Civil Status & 11.794 & ns & ns \\
\hline & Religion & 7.726 & ns & ns \\
\hline & Education & 17.602 & ns & ns \\
\hline & Occupation & 25.195 & $\mathrm{~s}$ & ns \\
\hline & Family Monthly Income & 5.471 & ns & ns \\
\hline & Family Size & 14.110 & ns & ns \\
\hline \multirow[t]{9}{*}{ Lack of materials } & Location & 10.440 & $\mathrm{~s}$ & ns \\
\hline & Age & 16.047 & ns & ns \\
\hline & Sex & 3.057 & ns & ns \\
\hline & Civil Status & 8.188 & ns & ns \\
\hline & Religion & 18.498 & $\mathrm{~s}$ & ns \\
\hline & Education & 14.940 & ns & ns \\
\hline & Occupation & 26.476 & $\mathrm{~s}$ & $\mathrm{~s}$ \\
\hline & Family Monthly Income & 14.323 & ns & ns \\
\hline & Family Size & 14.348 & ns & ns \\
\hline \multirow{9}{*}{$\begin{array}{l}\text { Lack of encouragement from the } \\
\text { extension agents assigned }\end{array}$} & Location & 4.393 & ns & $\mathrm{ns}$ \\
\hline & Age & 10.305 & ns & ns \\
\hline & Sex & 0.897 & ns & ns \\
\hline & Civil Status & 8.488 & ns & ns \\
\hline & Religion & 10.842 & ns & $\mathrm{ns}$ \\
\hline & Education & 18.060 & ns & ns \\
\hline & Occupation & 17.335 & ns & ns \\
\hline & Family Monthly Income & 15.236 & ns & $\mathrm{ns}$ \\
\hline & Family Size & 14.724 & ns & ns \\
\hline \multirow{9}{*}{$\begin{array}{l}\text { Insufficient extension agent that link } \\
\text { learning through training to the } \\
\text { community }\end{array}$} & Location & 6.517 & ns & $\mathrm{ns}$ \\
\hline & Age & 22.438 & $\mathrm{~s}$ & ns \\
\hline & Sex & 0.840 & ns & ns \\
\hline & Civil Status & 23.700 & $\mathrm{~s}$ & $\mathrm{~s}$ \\
\hline & Religion & 9.890 & ns & ns \\
\hline & Education & 13.158 & ns & ns \\
\hline & Occupation & 15.540 & ns & ns \\
\hline & Family Monthly Income & 23.861 & $\mathrm{~s}$ & ns \\
\hline & Family Size & 10.897 & ns & ns \\
\hline
\end{tabular}




\begin{tabular}{|c|c|c|c|c|c|}
\hline \multirow{9}{*}{\multicolumn{2}{|c|}{ Lack of capital }} & Location & 7.971 & ns & ns \\
\hline & & Age & 19.916 & ns & ns \\
\hline & & Sex & 2.801 & ns & ns \\
\hline & & Civil Status & 12.451 & ns & ns \\
\hline & & Religion & 7.971 & ns & ns \\
\hline & & Education & 12.234 & ns & ns \\
\hline & & Occupation & 20.199 & ns & ns \\
\hline & & Family Monthly Income & 12.322 & ns & ns \\
\hline & & Family Size & 12.685 & ns & ns \\
\hline \multirow{9}{*}{\multicolumn{2}{|c|}{ Financial resources are wasted }} & Location & 6.988 & ns & ns \\
\hline & & Age & 14.596 & ns & ns \\
\hline & & Sex & 2.027 & ns & ns \\
\hline & & Civil Status & 10.809 & ns & ns \\
\hline & & Religion & 8.371 & ns & ns \\
\hline & & Education & 20.812 & ns & ns \\
\hline & & Occupation & 18.369 & ns & ns \\
\hline & & Family Monthly Income & 21.508 & $\mathrm{~s}$ & ns \\
\hline & & Family Size & 13.287 & ns & ns \\
\hline \multirow{9}{*}{\multicolumn{2}{|c|}{$\begin{array}{l}\text { Financial resources } \\
\text { misappropriated }\end{array}$}} & Location & 6.113 & ns & ns \\
\hline & & Age & 15.965 & ns & ns \\
\hline & & Sex & 3.267 & ns & ns \\
\hline & & Civil Status & 6.649 & ns & ns \\
\hline & & Religion & 11.792 & ns & ns \\
\hline & & Education & 20.804 & ns & ns \\
\hline & & Occupation & 15.709 & ns & ns \\
\hline & & Family Monthly Income & 16.831 & ns & ns \\
\hline & & Family Size & 12.340 & ns & ns \\
\hline
\end{tabular}

Table 3 is the result of Pearson Correlation and Chi-square analysis. This was done to determine the relationship between independent and dependent variables and also to determine probability. Note that there is no correlation between variable $\mathrm{X}$ and variable $\mathrm{Y}$. (Null hypothesis) or we say that they are not related, or we say variable $\mathrm{X}$ does not affect $\mathrm{Y}$, and there is a correlation between variable $\mathrm{X}$ and variable $\mathrm{Y}$.

Table 4. Importance of the Skills or Tasks that are perceived by the Respondents

\begin{tabular}{|c|c|c|c|}
\hline Skills or Tasks & Mean & $\begin{array}{l}\text { Adjectival } \\
\text { Meaning }\end{array}$ & $\begin{array}{l}\text { Verbal } \\
\text { Interpretation }\end{array}$ \\
\hline Producing educational or teaching materials & 4.38 & Agree & Important \\
\hline Developing program budgets & 4.26 & Agree & Important \\
\hline Introduce a variety of useful methods and materials & 4.22 & Agree & Important \\
\hline Help learners learn from each other during learning activities & 4.20 & Agree & Important \\
\hline Show concern about learners as human beings & 4.20 & Agree & Important \\
\hline Appreciate local knowledge of learners and made use of it & 4.18 & Agree & Important \\
\hline Encourage the use of examples to illustrate concepts or practice & 4.16 & Agree & Important \\
\hline Determining information needed for evaluations & 4.16 & Agree & Important \\
\hline Assessing community needs & 4.16 & Agree & Important \\
\hline Encourage silent learners to participate & 4.16 & Agree & Important \\
\hline Uses understandable vocabulary & 4.14 & Agree & Important \\
\hline Help learners reflect critically on how they learn & 4.14 & Agree & Important \\
\hline Appreciate learning handicaps and disabilities & 4.14 & Agree & Important \\
\hline Promote discussion and learner interaction & 4.12 & Agree & Important \\
\hline $\begin{array}{l}\text { Respect racial ethnic and gender differences and their unique } \\
\text { contribution }\end{array}$ & 4.10 & Agree & Important \\
\hline Negotiate expectations and objectives & 4.10 & Agree & Important \\
\hline
\end{tabular}




\begin{tabular}{|c|c|c|c|c|}
\hline \multicolumn{3}{|l|}{ Establishing rapport } & Agree & Important \\
\hline \multicolumn{3}{|c|}{ Relate theory to practice } & Agree & Important \\
\hline \multicolumn{3}{|c|}{ Give step by step instructions } & Agree & Important \\
\hline \multicolumn{2}{|c|}{ Summarize the material presented } & 3.86 & Agree & Important \\
\hline \multicolumn{5}{|l|}{ Legend } \\
\hline $4.51-5.00$ & Strongly Agree & \multicolumn{3}{|l|}{ Highly Important } \\
\hline $3.51-4.50$ & Agree & \multicolumn{3}{|l|}{ Important } \\
\hline $2.51-3.50$ & Undecided & \multicolumn{3}{|l|}{ Neutral } \\
\hline $1.51-2.50$ & Disagree & \multicolumn{3}{|l|}{ Unimportant } \\
\hline $1.00-1.50$ & Strongly Disagree & \multicolumn{3}{|l|}{ Highly Unimportant } \\
\hline
\end{tabular}

The result shows that the participants on the information dissemination on mushroom production are from the Province of Lanao del Sur and Lanaodel Norte. Less than one half (44\%) of them are below 30 years old. More than one half $(58 \%)$ of them are female. More than one half $(54 \%)$ of them are married. Less than two thirds $(62 \%)$ of them are practicing Roman Catholic as a religion. More than one half $(56 \%)$ of them are in college level. More than one third $(36 \%)$ of them are into business. One half $(50 \%)$ of them have an income below $\square 5,000.00$. More than one third (38\%) of them have 1 to 3 family household family members. The respondents agree that seminar, lecture, method demonstration, group discussion, and meeting are effective extension teaching methods for information dissemination on mushroom production.

There is a sufficient evidence to show that there is correlation between location, age, and religionwiththe lack of understanding. There is a sufficient evidence to show that there is correlation between location and age with the lack of information. There is a sufficient evidence to show that there is correlation between location and agewith the lack of training. There is a sufficient evidence to show that there is correlation between location and lack of practical training on improved technology. There is a sufficient evidence to show that there is correlation between location, age, religion, occupation, and monthly incomewith the lack of adequate transportation to reach other informative events. There is a sufficient evidence to show that there is correlation between location, age, religion, occupation, and family sizewith the lack of access to resources. There is a sufficient evidence to show that there is correlation between age and occupationwith the materials are misappropriated. There is a sufficient evidence to show that there is correlation between locations, religion, and occupationwith the lack of materials. There is a sufficient evidence to show that there is correlation between age, civil status, and family incomewith theinsufficient agent that could link learning experiences to community application. There is a sufficient evidence to show that there is correlation between family monthly income and financial resources are wasted.

The respondents agree that producing educational or teaching materials developing program budgets; introduce a variety of useful methods and materials; cooperative learning, camaraderie among others, show concern about learners as human beings; appreciate local knowledge of learners and made use of it; encourage the use of examples to illustrate concepts or practice; determining information needed for evaluations; assessing community needs; encourage silent learners to participate; uses understandable vocabulary; help learners reflect critically on how they learn; appreciate learning handicaps and disabilities; promote discussion and learner interaction; respect individual differences; negotiate expectations and objectives; establishing rapport; relate theory to practice; give step by step instructions; and summarize the material presented are important skills or tasks.

Corollary to the findings of the study, Mabuza, Ortmann and Wale (2012) that gender, age and religion of the mushroom growers are influence positively with their trust and confidence with each other. Findings of Obaa and Nshemereirwe (2004) also showed that mushroom growers are mostly women and further trainings among growers were recommended. Study of Kimole (2012) made mentioned that inadequate knowledge and information on mushroom farming methods limits the farmers to prefer mushroom cultivation. Furthermore, his study revealed that insufficient or delay of mushroom seeds, insufficient capital and lack of knowledge were the major factor that hampered the mushroom growers. Dharmawardhana, Abeywickrama, Aravinda and Pelpola (2016) support the findings of Kimole (2012) and this study. The findings of their study showed that difficulty of obtaining reliable seeds, quality raw materials, quality of other inputs, unavailability of advisory or extension services, problem of finance and technical know-how are the major problems encountered by mushroom 
growers. Anent to this, supports from the family particularly among spouses significantly influences the activities in mushroom cultivation.

Febrianda and Tokuda (2018) pointed out in their study that partnership and continuous learning on mushroom farming through extension services and strategies will provide understanding about the process and appropriate management in mushroom cultivation. Through partnerships benefits for the farmers will be delivered successfully. They also added that production failure and market confusion among new mushroom growers will be prevented or minimize if continuous extensions services will be given by the extension service providers.

\section{Conclusion}

It can be concluded that the participants of the trainings and seminars that had been conducted belonged to the age below 30 years, female, married, adhere to Roman Catholic religion, finished tertiary level as their highest educational attainment, farmers and into business as their occupation, have a family monthly income of below five thousand pesos, and have a family member of one tothree members. Extension teaching methods such as seminar, lecture, method demonstration, group discussion, meeting, conference, achievement days, farmers field school, exhibits, farm and home visits, television, and field trip, are applicable in disseminating information on mushroom production. Application on disseminating information on mushroom productions such means as booklet, handouts, newspaper, brochures, radio, newsletter, result demonstration, fact sheet, photo novel, primer, role playing, bulletin, slides and film strips, leaflets, posters, wall newspaper, telephone calls, motion pictures, letters, office calls, and flyers are ineffective. There is correlation between some of the personal profiles and the effectiveness extension strategies on information dissemination on mushroom production. There are important skills or tasks in extension strategies on information dissemination on mushroom production.

\section{References}

[1] Dharmawardhana, Abeywickrama, Aravindaand Pelpola (2016). Potential of Improving Rural Livelihood through Mushroom Production: A Case Study of KamburupitiyaEkamuthuBimmalSamajaya

[2] Febrianda, R., Tokuda, H. (2018) Learning the Adoption of Mushroom Farming Partnership: A Case Study of Farmers and an Enterprise from Cianjur District, West Java, Indonesia. International Journal of Social cience StudiesVol. 6, No.7; July 2018ISSN 2324-8033E-ISSN 2324-8041Published by Redfame Publishing URL: http://ijsss.redfame.com1

[3] Kimole, S. (2012). The Adoption Of Mushroom Farming Among Smallholder Farmers: A case of women mushroom farmers in Makuyu, Kenya. A Research Project Submitted toVan Hall Larenstein University of Applied Sciences.

[4] Mabuza, ML.,Ortmann, G.F. and Wale, E.Z. (2012). Collective Action in Commercial Mushroom Production: The Role of Social Capital in the Management of Informal Farmer Groups in Swaziland.

[5] Obaa.and F. Nshemereirweb (2004). Assessing the Potential of Mushroom Cultivation in Improving Household Incomes of Smallholder Farmers. Department of Agricultural Extension Education, Faculty of Agriculture, Makerere University, P.O Box 7062, Kampala.Kawanda Agricultural Research Institute, P.O. Box 7065, Kampala (Uganda Journal of Agricultural sciences, 2004, 9: 656662 ISSN 1026-0919Printed in Uganda. All rights reserved. (C) 2004 National Agricultural Research Organization

[6] Shahi, V. Shahi, B. Kumar, V., Singh, KM and Kumari, P. (2018). Impact Study on Mushroom Cultivation for Microentrepreneurship Development and Women Empowerment. (19) (PDF) Impact study on mushroom cultivation for micro entrepreneurship development and women Available from:https://www.researchgate.net/publication/327337956_Impact_study_on_mushroom_cultivation_for_micro_entrepreneurship_dev elopment_and_women_Empowerment [accessed Feb 18 2019].August 2018

[7] Tanni, T.S., ShamimHasan, S., Md. MominulHoque, MdShamsuzzaman, K.M. and Moonmoon, M. (2012). Impact of Mushroom Cultivation on Socio-economic Status of Bangladeshi Beneficiaries National Mushroom Development and Extension Centre, Sobhanbag, Savar, Dhaka,

[8] Whittaker, C., Dickinson, H., Humphreys, J. \&Ramsammy, R. (1994). An Evaluation of Communication Strategies During The Process Of Incorporating A College Of Health Studies Into A University Journal Of Advanced Nursing, 19(4), 653-658.

[9] Yadav, R.K. (2008). A Study on Technological Gap in Recommended Mushroom Production Technology among the Farmers of Raipur District of Chhattisgarh State. Department of Agricultural Extension and Home Science College of Agriculture Indira Gandhi KrishiVishwavidyalaya

[10] Yongling, Z. (2004). Information Services in Rural China Field Surveys and Findings. RAP Publication. Food and Agriculture Organization of the United Nations Regional Office for Asia and the Pacific. Bangkok. 